\title{
PERANAN PERGURUAN TINGGI AGAMA ISLAM DI TENGAH KEBHINEKAAN DALAM MENUMBUHKAN KEWIRAUSAHAAN MAHASISWA MENGHADAPI MEA
}

\author{
Deddy Yusuf Yudhyarta \\ STAI Auliaurrasyidin Tembilahan \\ deddy.yusuf@stai-tbh.ac.id
}

\begin{abstract}
Abstrak
Mahasiswa merupakan aset dan harapan masa depan bangsa. Kemampuan berfikir dan belajar diharapkan dapat menjadi penggerak yang dinamis dalam pembangunan, mampu menemukan solusi yang tepat dalam menyelesaikan masalah kebhinekaan, turut andi lmengatasi masalah pengangguran. Namun, data pengangguran terdidik diIndonesia menunjukkan bahwa semakin tinggi pendidikan seseorang, semakin rendah kemandirian dan semangat kewirausahaan. Peranan Perguruan Tinggi Agama Islam dituntut menyiapkan mahasiswa agar menjadi lulusan yang mampu bersaing. Upaya penyiapan mahasiswa dalam menghadapi MEA dapat dilakukan melalui jalur akademik dan nonakademik. Bersinergi dan berkesinambungan agar memiliki karakter yang mampu menjadikannya bersaing, inisiatif, integritas, komitmen, kreatif, mandiri, manajemen diri, dan kerjasama.
\end{abstract}

Kata Kunci: Mahasiswa, Peranan,PerguruanTinggi Agama Islam, Kebhinekaan, kewirausahaan 


\section{A. Pendahuluan}

Sebagai negara berpenduduk muslim terbesar di dunia, sebaiknya umat muslim Indonesia menjadikan Qur'an sebagai pedoman hidup, karena ayatayatnya mengandung ilmu pengetahuan lebih dari 780 kali digunakan. Hal ini bermakna bahwa ajaran Islam sebagaimana tercermin dari Qur'an sangat kental dengan nuansa-nuansa yang berkaitan dengan ilmu, sehingga dapat menjadi ciri penting dari agama Islam sebagaimana dikemukakan oleh Dr Mahadi Ghulsyani yang mengatakan, salah satu ciri yang membedakan Islam dengan yang lainnya adalah penekanannya terhadap masalah ilmu (sains), Qur'an dan Sunnah mengajak kaum muslim untuk mencari dan mendapatkan Ilmu dan kearifan, serta menempatkan orang-orang yang berpengetahuan pada derajat tinggi. (Saputra, 2017)

Indonesia merupakan negara yang memiliki kebhinekaan sebaiknya dipahami sebagai sebuah kekuatan pemersatu bangsa. Kebhinekaan juga harus dimaknai masyarakat melalui pemahaman multikulturalisme berlandaskan kekuatan spiritualitas, maksudnya masyarakat melihat perbedaan itu sebagai sebuah keragaman yang mempersatukan, menerima perbedaan sebagai sebuah kekuatan bukan sebagai ancaman atau gangguan. Karena perkembangan dan kemajuan suatu bangsa ditentukan oleh sejauh mana sumber daya manusia menguasai ilmu pengetahuan dan teknologi untuk dimanfaatkan bagi kesejahteraan dan kemakmuran bangsa.

Suatu lembaga yang relevan dan bertanggung jawab untuk menghasilkan sumber daya manusia unggul dan berkualitas yang menguasai ilmu pengetahuan dan teknologi adalah perguruan tinggi. Perguruan tinggi sebagai centre of excellence hendaknya mampu mencetak sumber daya manusia yang berkualitas penuh dengan tantangan dan persaingan di dunia pendidikan, tidak sepertinya hanya aspek trading dan traveling yang sarat dengan muatan-muatan ekonomi (kapitalisme) di balik menglobalnya kedua aspek tersebut. Terlebih lagi, masalah pendidikan ini pada hakikat 
merupakan satu usaha sadar manusia untuk memberikan layanan sosial kepada masyarakat, sehingga memiliki kematangan, kedewasaan dan kecakapan hidup, baik dalam konteks aktualisasi diri maupun relasi dengan sesama warga negaranya. Hakikat dasar pendidikan inilah yang sesungguhnya menjadi salah satu pengerem atau lambatnya dunia pendidikan mengalami proses globalisasi. (Darmawan, 2014)

Indonesia saat ini sudah menerapkan standar nasional pendidikan sesuai dengan PP No. 13 tahun 2015, tentang standar nasional pendidikan, Itulah sebabnya pendidikan harus mencapai standar isi, standar proses sampai standar penilaian pendidikan, antara lain agar meningkatkan daya saing dengan negara-negara di dunia umumnya dan ASEAN khususnya. Saat ini Indonesia secara ekonomi daya saingnya rendah sekali dibandingkan dengan negara-negara ASEAN. Menurut UNDP posisi Indonesia dalam (HDI) human resourch development index, pada tahun 2016 pada peringkat 113 dari 188 negara di dunia bahkan di ASEAN.

Persaingan dunia pendidikan antar negara ASEAN, jika di lihat dari data Badan Pusat Statistik (BPS) menunjukkan, pengangguran pemuda terdidik februari 2017 masih mencapai 36,53\%. Jumlah pengangguran terdidik terbanyak adalah lulusan perguruan tinggi $(11,33 \%)$ atau setara dengan 792.130 orang, lulusan SMA (7,03\%), SMK (9,27\%), SMP (5,36\%), dan SD (3,54\%). Ini tampak jelas dari gambar grafik di bawah. 


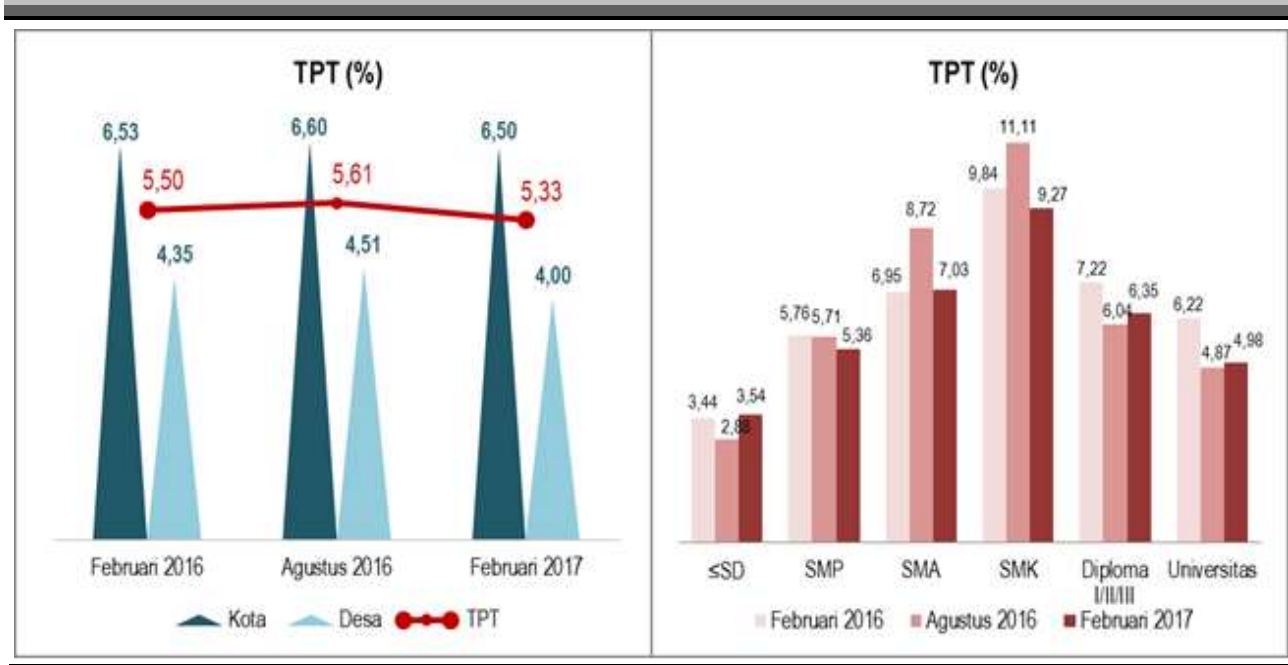

Sumber:Berita Resmi Statistik No. 47/05/Th. XX, 05 Mei 2017

Lulusan perguruan tinggi Indonesia jika di lihat dari gambar grafik di atas menunjukan dunia perguruan tinggi di Indonesia sedang mengalami dilema, sebab gelar ijazah pendidikan tinggi yang mereka raih tak lagi jadi jaminan mudah untuk mendapat pekerjaan. Kesulitan mereka terserap dunia kerja semakin bertambah berat, karena sejak tanggal 31 Desember 2015 mereka juga bersaing dengan tenaga kerja asing dari negara-negara ASEAN sebagai dampak berlakunya Masyarakat Ekonomi Asean (MEA)

Kondisi di atas mengisyaratkan betapa masalah pengangguran terdidik menjadi masalah yang sangat serius, karena data pengangguran terdidik di Indonesia menunjukkan bahwa semakin tinggi pendidikan seseorang, semakin rendah kemandirian dan semangat kewirausahaannya. Kondisi yang dihadapi akan semakin diperburuk dengan situasi persaingan global regional ASEAN, dimana lulusan perguruan tinggi Indonesia bersaing secara bebas dengan lulusan dari perguruan tinggi asing. Oleh karena itu, para sarjana lulusan perguruan tinggi perlu diarahkan dan didukung untuk tidak hanya berorientasi sebagai pencari kerja (job seeker), sebaliknya siap menjadi pencipta pekerjaan (job creator) juga.

Berdasarkan latar belakang tersebut dan perubahan-perubahan tersebut berimbas pada substansi, struktur, dan budaya, maka tulisan ini mengambil 
judul tentang "Peranan Perguruan Tinggi Agama Islam di Tengah Kebhinekaan dalam Menumbuhkan Kewirausahaan Mahasiswa Menghadapi MEA".

\section{B. Metodologi}

Penelitian ini berbentuk field research dalam bahasa Arab dikenal dengan istilah al-bahts al-maidanyi menggunakan metode deskriptif kualitatif. Penggunaan metode ini berfungsi untuk melihat, meninjau, mengetahui dan memaparkan serta mengungkapkan sesuatu menurut apa adanya (Raichul Amar, 2007 : 52). Penelitian dengan judul seperti digambarkan di atas merupakan penelitian deskriptif kualitatif. Metode penelitian kualitatif sering disebut dengan metode penelitian naturalistik, hal itu menurut Sugiyono (2011: 14) karena dilakukan dalam kondisi yang alamiah, data yang terkumpulpun kelak akan dianalisis secara kualitatif pula.

Sementara menurut Luthfi ( 2005 : 57 ), penelitian dengan metode kualitatif merupakan penelitian yang menghasilkan data deskriptif berupa kata-kata tertulis dan prilaku yang dapat diamati. Bentuk penelitian kualitatif ini sengaja dipilih kerena menurut penulis/peneliti hanya bertumpu pada pengumpulan data melalui observasi, wawancara, dan metode lainnya yang dapat menghasilkan data secara deskriptif pula. Untuk penelitian kualitatif perlu ditambahkan kehadiran peneliti, subjek peneliti, informan yang ikut membantu beserta cara-cara menggali data-data penelitian, lokasi dan lama penelitian serta uraian mengenai pengecekan keabsahan hasil penelitian.

Dengan redaksi yang berbeda, Arief Furchan (2005:15) menjelaskan hakikat penelitian kualitatif itu adalah prosedur penelitian yang menghasilkan data deskriptif. Penelitian yang mendeskripsikan suatu gejala, fakta, peristiwa atau kejadian yang sedang atau yang sudah terjadi, yaitu 
tentang Peranan Perguruan Tinggi Agama Islam di Tengah Kebhinekaan dalam Menumbuhkan Kewirausahaan Mahasiswa Menghadapi MEA.

\section{Hasil}

Sebenarnya bangsa Indonesia sudah siap menghadapi MEA. Asalkan pemerintah dan mahasiswa sadar akan kemampuan diri dan memahami nilai kebangsaan Indonesia secara baik. Pada era globalisasi sekarang ini, negara Indonesia memerlukan kerjasama antar semua golongan supaya bisa bersaing dengan negara lain. Bangsa Indonesia dari berbagai ras, suku, bahasa, agama dan budaya, diharapkan terus bekerja keras untuk mengharumkan nama bangsa diberbagai belahan dunia dengan prestasi dan bidangnya masing-masing. Pengangguran merupakan salah satu masalah serius yang kita hadapi. Karena dari pengangguran berbagai patologi sosial dapat terjadi. Perguruan Tinggi Agama Islam (PTAI) dapat berperan.

\section{Pembahasan}

Pembentukan MEA berawal dari kesepakatan para pemimpin ASEAN dalam Konferensi Tingkat Tinggi (KTT) pada Desember 1997 di Kuala Lumpur, Malaysia. Kesepakatan ini bertujuan meningkatkan daya saing ASEAN serta bisa menyaingi Tiongkok dan India untuk menarik investasi asing. Modal asing dibutuhkan untuk meningkatkan lapangan pekerjaan dan kesejahteraan warga ASEAN.

Selain peluang yang terlihat di depan mata, ada pula hambatan menghadapi MEA yang harus kita perhatikan. Hambatan tersebut di antaranya di kutip http://www.bppk.kemenkeu.go.id/publikasi/artikel/150artikel-keuangan-umum/20545-masyarakat-ekonomi-asean-mea-danperekonomian-indonesia, diakses tanggal 5 mei 2017:

1. Mutu pendidikan tenaga kerja masih rendah.

2. Ketersediaan dan kualitas infrastuktur masih kurang sehingga mempengaruhi kelancaran arus barang dan jasa.

3. Sektor industri yang rapuh karena ketergantungan impor bahan baku dan setengah jadi. 
4. Keterbatasan pasokan energi.

5. Lemahnya Indonesia menghadapi serbuan impor.

Adanya MEA diharapkan perekonomian Indonesia menjadi lebih baik. Salah satunya adalah pemasaran barang dan jasa dari Indonesia dapat memperluas jangkauan ke negara ASEAN lainnya dengan biaya yang lebih murah. Tenaga kerja dari negara-negara lain di ASEAN bisa bebas bekerja di Indonesia.

Salah satu nilai tambah negara Indonesia di banding dengan negara ASEAN lainnya, adalah sumber daya Kebhinekaan. Seharusnya hal ini dapat dipahami sebagai sebuah kekuatan pemersatu bangsa. Kebhinekaan juga harus dimaknai masyarakat melalui pemahaman multikulturalisme berlandaskan kekuatan spiritualitas, maksudnya masyarakat melihat perbedaan itu sebagai sebuah keragaman yang mempersatukan, menerima perbedaan sebagai sebuah kekuatan bukan sebagai ancaman atau gangguan. Semua budaya, agama dan suku yang ada tetap pada bentuknya masingmasing, yang mempersatukan adalah rasa nasionalisme kebanggaan sebagai bangsa Indonesia. Kemajemukan dan keragaman budaya adalah sebuah fenomena yang tidak mungkin dihindari karena keragaman budaya merupakan bagian dari proses kemajemukan. Dalam menghadapi kemajemukan tentu saja tidak mungkin mengambil sikap anti pluralisme karena harus belajar toleran tehadap kemajemukan dan dituntut untuk hidup di atas dasar, semangat pluralisme agama (Johan Effendi, 2004 : 61)

Kebhinekaan adalah sumber persatuan bangsa Indonesia, dan Pancasila adalah landasan dasar yang mengajarkan nilai semuanya, namun saat ini Pancasila sudah dianggap usang. Ada beberapa upaya yang perlu dilakukan agar nilai kebhinekaan dan multikulturalisme di Indonesia tidak memburuk yaitu : Pertama, perlunya literasi media khususnya bagaimana menggunakan media sosial secara bijaksana. Media sosial yang berkembang pesat menjadikan apapun dapat tersebar masuk langsung ke privat 
masyarakat, jika tanpa ada filter, kroscek dan literasi medsos yang berkesinambungan ke masyarakat, maka yang terjadi adalah saling klaim kebenaran ataupun kesalahan. Kedua, saat ini pentingnya mengembalikan pendidikan moral baik dalam informal dan formal, karena keberagamaan, toleransi dan saling menghormati dapat tumbuh diawali dari pendidikan terbawah informal yaitu keluarga. Ketiga, mahasiswa sebagai agen perubahan harus ikut memikirkan kondisi nasional, jika tidak maka bersiaplah menjadi mahasiswa korban industrial pendidikan yang tidak mampu mengimplementasikan dharma pendidikan, padahal pendidikan adalah membebaskan bukan sekedar mencerdaskan. Faktor kunci membebaskan itulah yang dapat membuat nilai kebhinekaan dan multikulturalisme kita semakin dinamis dan elastis. https://suaradewata. com/read/2017/01/06/201701060003/Nilainilai-Kebhinekaan-Dalam-Multi kulturalisme-dan-Ancamannya.html, diakses tanggal 12 Juni 2017

Berbagai konsep yang relevan dengan multikulturalisme antara lain adalah demokrasi, keadilan dan hukum, nilai-nilai budaya dan etos, kebersamaan dalam perbedaan yang sederajat, kesukubangsaan, kebudayaan, keyakinan keagamaan, ungkapan-ungkapan budaya, domain privat dan publik, HAM, hak budaya komunitas, dan konsep-konsep lainnya yang relevan.

Menurut McClelland dalam Kasali, salah satu faktor yang menyebabkan sebuah negara menjadi maju adalah ketika jumlah wirausaha yang terdapat di negara tersebut minimal $2 \%$ dari populasi penduduknya. Saat ini jumlah wirausaha di Indonesia baru mencapai $1,56 \%$, bila dibandingkan dengan Amerika Serikat (11,5\%) dan Singapura (7,2\%). Dengan jumlah penduduk Indonesia sebesar 250 juta, maka dibutuhkan sekitar 5 juta wirausaha. Jika hal ini dibiarkan tanpa upaya menumbuhkannya, maka sangat lambat untuk memenuhi angka 2\% wirausaha. Menjadi wirausaha adalah salah satu pilihan untuk memajukan 
bangsa ini. Oleh karena itu, perubahan pola pikir tentang kewirausahan perlu ditumbuhkan melalui pendidikan formal maupun non formal. (MODUL KEWIRAUSAHAAN Untuk Mahasiswa, 2015, Pusat Kewirausahaan Universitas Negeri Makassar.) https://bwfitri.files.wordpress.com/2011/12/ebook-modul-kewirausahaanuntuk-mahasiswa.pdf. diakses tanggal 5 mei 2017.

Zimmerer http://puslit2.petra.ac.id/ejournal/index.php/man/article/ viewFile/18329/18174.Zimmerer,W.T..EssentialsofEntrepreneurship and SmallBusinessManagement.Third Edition. (NewYork:Prentice-Hall,2002), Lihat dalam Lieli Suharti dan Hani Sirine, "Faktor-Faktor yang Berpengaruh Terhadap Niat Kewirausahaan (Entrepreneurial Intention) (Studi Terhadap Mahasiswa Universitas Kristen Satya Wacana, Salatiga)”, Jurnal Manajemen Dan Kewirausahaan, Vol.13, NO.2, September2011., diakses tanggal 1 mei 2017), menyatakan bahwa salah satu faktor pendorong pertumbuhan kewirausahaan disuatu negara terletak pada peranan perguruan tinggi/universitas melalui penyelenggaraan pendidikan kewirausahaan. Pihak universitas bertanggung jawab dalam mendidik dan memberikan kemampuan wirausaha kepada para lulusannya dan memberikan motivasi untuk berani memilih berwirausaha sebagai karir mereka. Pihak perguruan tinggi perlu menerapkan pola pembelajaran kewirausahaan yang kongkrit berdasar masukan empiris untuk membekali mahasiswa dengan pengetahuan yang bermakna agar dapat mendorong semangat mahasiswa untuk berwirausaha. (Yohnson. 2003. Peranan Universitas dalam Memotivasi Sarjana Menjadi Young Entrepreneurs. Jurnal Manajemen dan Kewirausahaan, 5(2):97-111.Bacajuga $\mathrm{Wu}, \mathrm{S} . \& \mathrm{Wu}, \mathrm{L} .2008$. TheImpactof Higher Education on Entrepreneurial Intentionsof University Studentsin China. Journal of Small Businessand Enterprise Development,15(4),h.752-774. 


\section{Islam Dan Wirausaha}

Islamm emang tidak memberikan penjelasan secara eksplisit tentang konsep kewirausahaan (entrepreneurship), namun di antara keduanya mempunyai kaitan yang cukup erat; memiliki ruh atau jiwa yang sangat dekat, meskipun bahasa teknis yang digunakan berbeda. Dalam Islam beberapa istilah digunakan sebagai isyarat atas jiwa wirausaha, diantaranya yaitu kerja keras, kemandirian (biyadihi), dan ulet.

Setidaknya terdapat beberapa ayat Qur'an yang dapat menjadi rujukan pesan tentang perintah untuk beramal, kerja keras dan kemandirian ini. Allah berfirman:

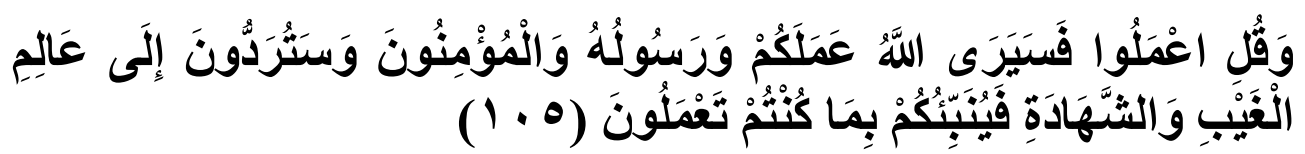

Artinya:

Dan Katakanlah, "Bekerjalah kamu, maka Allah dan Rasul-Nya serta orang-orang mukmin akan melihat pekerjaanmu itu, dan kamu akan dikembalikan kepada (Allah) Yang Mengetahui akan yang ghaib dan yang nyata, lalu diberitakan-Nya kepada kamu apa yangtelah kamu kerjakan."

Dalam surat Al-Jum'ahayat 10, Allah SWT mengingatkan kita, umat Islam, agar setelah menjalankan shalat Jumah, mereka pergi untuk mencari meraih rizki karunia Allah. Meskipun ketika bekerja, umat Islam mesti tetap selalu ingat kepada Allah. Dengan selalu ingat kepada Allah, seorang muslim tentunya akan menjauhkan diri dari berbagai perilaku yang dilarang Allah, misalnya melakukan perbuatan curang, yang merugikan orang lain, mengurangi timbangan, tidak jujur, serta menyembunyikan cacat barang dagangannya dan lain sebagainya.

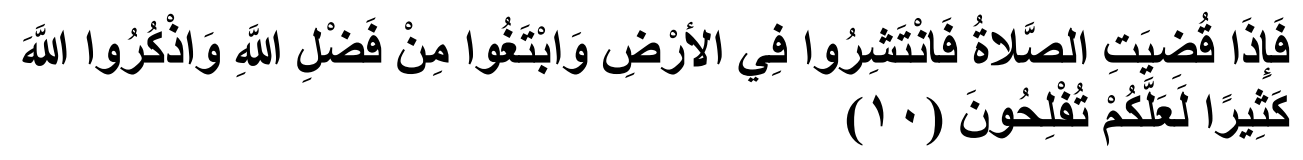

Artinya:

Apabila telah ditunaikan shalat, maka bertebaranlah kamu di muka 
bumi; dan carilah karunia Allah dan ingatlah Allah banyakbanyak supaya kamu beruntung.

Ayat ini juga menunjukan, bahwa bekerja merupakan kewajiban bagi seorang muslim, setelah dia melaksanakan kewajiban menyembah Allah. Karena bekerja bukan saja berarti untuk memenuhi atau mencukupi kebutuhan keluarga, namun juga memiliki banyak fungsi, diantaranya mencegah untuk jatuh ke dalam perbuatan yang dilarang, seperti mencuri, meminta-minta, serta mengharap pemberian orang lain. Bekerja juga menjadikan seorang muslim memiliki iffah, harga diri dihadapan orang lain. Dalam surat Annisa'ayat 32 Allah berfirman:

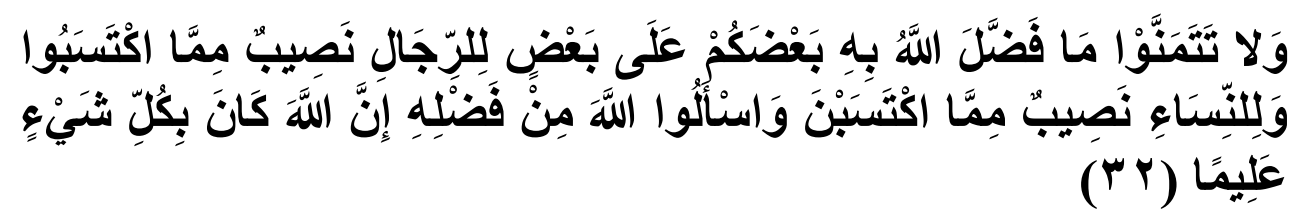

Artinya:

Dan janganlah kamu iri hati terhadap apa yang dikaruniakan Allah kepada sebahagian kamu lebih banyak dari sebahagian yang lain. (karena) bagi orang laki-laki ada bahagian dari pada apa yang mereka usahakan, dan bagi Para wanita (pun) ada bahagian dari apa yang mereka usahakan, dan mohonlah kepada Allah sebagian dari karunia-Nya. Sesungguhnya Allah Maha mengetahui segala sesuatu.

Dalam surat An-Nisa' ayat 32 ini Allah mengingatkan kepada umat Islam agar giat berusaha, karena Allah akan memberi anugerah dan karunia kepada yang mau giat bekerja, baik laki-laki maupun perempuan. Dan Allah mengingatkan agar kaum muslimin menjauhi sifat iri atas karunia yang diberikan Allah kepada sebagian kaum muslim yang lain, karena Allah memberi karunia berdasarkan besarnya usaha yang mereka lakukan. Ayat ini mengisyaratkan bahwa bekerja merupakan kunci membuka karunia Allah.

Sejarah mencatat, bahwa Rasulullah SAW, istrinya dan sebagian besar sahabatnya, adalah para pedagang dan entrepreneur, hal ini menunjukkan 
bahwa Rasulullah bukan hanya memotivasi umatnya untuk bekerja keras lewat sabdanya, namun beliau juga memberikan contoh taula dan, beliau pekerja keras, praktisi ekonomi, seorang pedagang yang ulet dan sosok panutan bagi umat. Bukanlah Islam adalah agama kaum pedagang, disebarkan keberbagai belahan dunia oleh para pedagang muslim. Islam bisa sampai keIndonesia, salah satunya lewat jalur perdagangan.

\section{Peranan Perguruan Tinggi Keagamaan Islam Meningkatkan Kewirausahan di Era MEA}

Berbagai literatur, perguruan tinggi diharapkan dapat mengelola, mengendalikan, merekayasa, memperbaiki dan merekonstruksi masyarakat. Tata sosial, perilaku sosial, dan perubahan sosial diusahakan tetap berdasarkan pada falsafah hidup yang ada di masyarakat. Fungsi dari ketiga perguruan tinggi ini kemudian muncul peran perguruan tinggi yang disebut tridarma atau tiga pengabdian perguruan tinggi yang ketiganya saling terpadu, yaitu darma pendidikan dan pengajaran (teaching and learning), darma penelitian, dan darma pengabdian. Perbedaan fungsi dan darma, adalah fungsi berkaitan dengan tugas dan darma berkaitan dengan peran.

Melalui pendidikan, dapat ditanamkan nilai-nilai kepribadian, karakterwirausaha dan wawasan kewirausahaan kepada mahasiswa peserta didik. Jalur penelitian merupakan jalur inovasi dan evaluasi kewirausahaan yang bermanfaat dalam peningkatan kualitas, jenis produk dan perluasan wilayah jangkauan kewirausahaan. Kegiatan pengabdian kepada masyarakat sebagai jalur pembinaan dan pengembangan kewirausahaan dapat dilakukan dengan me-leanding - kanhasil penelitian dilapangan (masyarakat). Berbagai inovasi, dan temuan dapat dimanfaatkan dimasyarakat. Dengan menjadikan tridharma sebagai frame pengambangan kewirausahaan bagimahasiswa, maka menjadikan perguruan tinggi sebagai pusat pengembangan wirausaha dapat dicapai.

Liberalisasi ekonomi yang terwujud dalam gagasan MEA bisa 
memberikan dampak yang positif dan membawa kemakmuran yang luar biasa. Di sisi lain akan menimbulkan kesenjangan ekonomi yang semakin tampak jelas. Karena itu, kedewasaan masyarakat sangat berarti bila negara tersebut berada pada kebijakan ekonomi terbuka. Segenap elemen masyarakat dituntut untuk lebih memerhatikan dengan saksama terkait dengan hal tersebut. Termasuk mahasiswa di Indonesia, sebagai generasi penerus yang diharapkan siap dan mumpuni sehingga mampu menghadapi kondisi pasar terbuka MEA.Langkah-langkah konkret yang bisa dilakukan mahasiswa dalam menghadapi MEA adalah https://www.cermati.com/artikel/inilah-peran-penting-mahasiswa-dalammea. Diakses, Tanggal 20 Januari 2017.:

a. MEA Menjadi Ajang Pembuktian Mahasiswa dalam Dunia Kerja

b. Pengembangan Keilmuan Jadi Fokus Mahasiswa untuk Bersaing dalam MEA

c. Mengasah Diri dan Mengejar Ketertinggalan Mesti Dilakukan Mahasiswa

d. Peran Aktif Mahasiswa Diperlukan dalam Menumbuhkan Kewirausahaan Apalagi dalam Era MEA.

Menumbuhkan jiwa kewirausahaan para mahasiswa, perguruan tinggi merupakan alternatif untuk mengurangi tingkat pengangguran, karena sarjana diharapkan dapat menjadi wirausahawan muda terdidik yang mampu merintis usahanya sendiri. Lebih lanjut, menyikapi persaingan dunia bisnis masa kini dan masa depan yang lebih mengandalkan pada knowledge dan intelectual capital, maka agar dapat menjadi daya saing bangsa, pengembangan wirausahawan muda perlu diarahkan pada kelompok orang muda terdidik.

Usaha-usaha yang dapat dilakukan oleh perguruan tinggi dalam menumbuhkan jiwa wirausaha pada mahasiswa antara lain:

a. Menetapkan mata kuliah kewirausahaan pada setiap jurusan/program 
studi. Keberadaan mata kuliah kewirausahaan penting untuk meningkatkan motivasi dan dapat membuka wawasan yang lebih luas bagi mahasiswa terhadap kewirausahaan.

b. Mengadakan seminar tentang kewirausahaan dengan mendatangkan para ahli dan praktisi wirausaha. Seminar yang mendatangkan ahli dari luar kampus dan praktisi wirausaha muda yang sukses tentu menarik bagi mahasiswa. Mahasiswa akan termotivasi untuk menjadi wirausaha.

c. Membentuk jaringan sistem kemitraan secara lintas instansional. Perguruan tinggi dapat membuat jaringan kewirausahaan dengan pemerintah, dunia usaha dan industri, dan LSM kewirausahaan, serta Badan-badan Kewirausahaan yang ada baik Nasional maupun Internasional LiaYuliana, dalam "Peranan Perguruan Tinggi Dalam Mengembangkan Sikap Mental Kewirausahaan Mahasiswa",Prodi Manajemen Pendidikan FIPUNY. Jaringan ini akan membantu dalam pendidikan, dan dapat juga menjadi tempat penyaluran sarjana yang merintis dunia wirausaha.

d. Memberikan permodalan pinjaman lunak kepada mahasiswa. Permasalahan yang sering muncul ketika kita menanyakan alasan mahasiswa sehingga enggan berwirausaha adalah ketiadaan modal.

Kompleksnya permasalahan dunia usaha saat ini, menuntut seseorang yang ingin menjadi wirausahawan tidak cukup bakat saja. Ada orang yang belum menyadari bahwa ia memiliki bakat sebagai wirausahawan, tetapi setelah mengikuti pendidikan, pelatihan ataupun bergaul di lingkungan wirausaha akhirnya ia menyadari dan mencoba memanfaatkan bakat yang dimilikinya Rusdiana, (2014). Kewirausahaan Teori dan Praktik. Bandung: Pustaka Setia. h. 56-57. 


\section{E. Kesimpulan}

Seharusnya PTAI tidak hanya sekadar mampu menyediakan tenaga kerja, namun juga mampu menciptakan para entrepreneur atau wirausaha dan inovator. Usaha-usaha yang dapat dilakukan oleh perguruan tinggi dalam menumbuhkan jiwa wirausaha pada mahasiswa antara lain: Pertama, Menetapkan mata kuliah kewirausahaan pada setiap jurusan/program studi; Dua, Mengadakan seminar tentang kewirausahaan; Tiga, Membentuk jaringan sistem kemitraan secara lintas instansional; Empat, Memberikan permodalan pinjaman lunak kepada mahasiswa.

Berdasarkan pemikiran di atas, maka dibutuhkan ada upaya seksama dan sistematik sehingga pemerintah dapat menyelenggarakan pendidikan tinggi sesuai dengan visi dan misi pembangunan nasional Indonesia, khususnya dalam konteks menuntaskan gerakan reformasi nasional yang tengah berjalan seperti ini. Bila hal ini tidak dilakukan, maka pendidikan tinggi di Indonesia, hanyalah akan menjadi salah satu instrumen kepentingan orang lain, dan bukan bagian dari upaya pembangunan karakter bangsa negerinya sendiri

Pada konteks inilah, fungsi pendidikan sebagai bagian pembangunan karakter bangsa (national character building) harus tetap dipertahankan meski adanya tekanan dan tuntutan globalisasi. Sebab, pendidikan hakikatnya sebuah keniscayaan untuk mengembangkan sumber daya manusia sebagai modal sosial (social capital). Hal yang lebih prinsip lagi, melalui pembaharuan filsafat, sistem, dan model penyelenggaraan pendidikan global berbasiskan nilai ke-Indonesiaan ini, diharapkan dapat dijadikan landasan dalam membangun karakter kewarga- negaraan bangsa Indonesia yang kokoh ke dalam dan ke luar. Ke dalam artinya, pendidikan memiliki peran dalam meningkatkan ketahanan nasional Indonesia dalam menjaga keutuhan negara, sekaligus memiliki standar mutu pendidikan yang baik. Sedangkan kokoh ke luar, artinya pendidikan mesti mampu 
membangun karakter anak bangsa dalam mewujudkan global (global citizenship ) atau global civil society (masyarakat sipil global) sehingga mampu bersaing dengan warga dunia lainnya.

\section{Referensi}

Alma, Buchari. (2016). Kewirausahaan. Bandung: Alfabeta.

Berita Resmi Statistik No. 47/05/Th. XX, 05 Mei 2017

Drucker, Peter F. Inovasi dan Kewiraswastaan, Praktek dan Dasar-dasar, terjamah: Rusdji Naib(Jakarta: Erlangga,1996).

Effendi, Johan. Kemusliman dan Kemajemukan Agama (Yogyakarta: Pustaka Pelajar, 2004), h. 61

http://edukasi.kompas.com/read/2016/04/23/17424071/ Akses 14 mei 2017

http://puslit2.petra.ac.id/ejournal/index.php/man/article/viewFile/18329/181 74. Zimmerer,W.T.. Essentialsof Entrepreneur ship and Small Business Management. Third Edition. (NewYork:Prentice-Hall,2002), Lihat dalam Lieli Suharti dan Hani Sirine, "Faktor-Faktor yang Berpengaruh Terhadap Niat Kewirausahaan (Entrepreneurial Intention) (Studi Terhadap Mahasiswa Universitas Kristen Satya Wacana, Salatiga)", Jurnal Manajemen Dan Kewirausahaan, Vol.13, NO.2, September2011., diakses tanggal 1 mei 2017

http://hdr.undp.org/en/2016-report. Diakses Tanggal 15 Mei 2017.

https://www.setneg.go.id/index.php?option=com_content\&task=view\&id=6 372. Cecep Darmawan, "Merekonstruksi, Pendidikan di Era Global", dalam Jurnal Sekretariat Negara RI No.19, februari 2014, diakses tanggal 12 mei 2017

https://www.academia.edu/9601085/LATAR_BELAKANG_TERBENTUK NYA_MEA_ATAU_AEC_2015, diakses 3 Mei 2017

Kasali, Renald dkk, Modul Kewirausahaan untuk Program Stratal, (Bekasi: Rumah Perubahan, 2010). h. 7

Kasmir, Kewirausahaan, (Jakarta: Raja Grafindo Persada, 2008). 
Mikhael Gewati,Kenapa.Lulusan.Perguruan.Tinggi.Makin.Susah.Mendapat. Pekerjaan. http://edukasi.kompas.com/read/2016/04/23/17424071/ Akses 14 mei 2017

Rusdiana, (2014). Kewirausahaan Teori dan Praktik. Bandung: Pustaka Setia

Sanusi, A. Pendidikan Alternatif Menyentuh Aras Dasar Persoalan Pendidikan dan Kemasyarakatan. (Bandung: Program Pascasarjana UPI Bandung, 2005).

Sudradjat Rasyid dkk, Kewirausahaan Santri, Bimbingan Santri Mandiri, (Jakarta: Citra yudha Alamanda Perdana, $t$ t).

Suharti, Lieli dan Hani Sirine, "Faktor-Faktor yang Berpengaruh Terhadap Niat Kewirausahaan (Entrepreneurial Intention) (Studi Terhadap Mahasiswa UniversitasKristen Satya Wacana, Salatiga)", Jurnal Manajemen Dan Kewirausahaan, Vol.13, NO. 2, September 2011:

Yohnson. 2003. Peranan Universitas dalam Memotivasi Sarjana Menjadi Young Entrepreneurs. Jurnal Manajemendan Kewirausahaan, 5 (2):97111. Bacajuga Wu, S. \& Wu, L. 2008. TheImpactof Higher Education on Entrepreneur alIntentionsof University Studentsin China. Journal of Small Business and Enterprise Development, 15 (4).

Yuliana, Lia, dalam "Peranan Perguruan Tinggi Dalam Mengembangkan Sikap Mental Kewirausahaan Mahasiswa", Prodi Manajemen Pendidikan FIPUNY. 